\title{
Development of Kampus Merdeka-Merdeka Belajar Method for the Sejarah Indonesia Kontemporer Course Through Student Independent Project: A Research Report
}

\author{
Yudhi Andoni ${ }^{1, *}$ Wannofri Samry ${ }^{2}$ \\ ${ }^{1}$ History Department, Andalas University \\ ${ }^{2}$ History Departments, Andalas University
}

"Corresponding author. Email: yudhiandoni@hum.unand.ac.id

\begin{abstract}
The focus of this research is the experience of students taking contemporary Indonesian history courses with the independent project method to see if the method is an effective, efficient, and inspirational way of learning for students in the context of developing Kampus Merdeka-Merdeka Belajar at the history department, Andalas University. This research method is qualitative, based on video data produced by students and questionnaires distributed to them. Based on the data, it was found that more than seventy percent of students liked the learning method using independent projects. Their reason is because this method gives them the hard skills and the soft skills needed after graduation, as well as experience of interacting directly with the community.
\end{abstract}

Keywords: independent project, kampus merdeka-merdeka belajar, hard-skills, soft-skills

\section{INTRODUCTION}

The Contemporary Indonesian History course in the KKNI curriculum structure which is being implemented this semester in the History Department, Faculty of Humanities, Andalas University is part of the compulsory subject composition. This subject is compulsory for fourth-semester history students. However, this course is not part of a conditional course, but a continuation of the previous courses that have exposed the history of Indonesia since the 16th century.

The subject "Sejarah Indonesia Kontemporer" discusses the dynamics or changes that have occurred in the history of the contemporary era. The contemporary era in question is from the early days of Indonesian independence to the 1990s. The materials discussed and understood by students taking this course concerns the Japanese occupation of Indonesia, the making process of the 1945 Constitution, and the formation of military institutions, followed by the phenomenon of Indonesia at the beginning of independence to the era of Liberal Democracy, Guided Democracy, regional upheaval, political upheaval that gave birth to the New Order Regime. The final material for the lecture discusses the condition of Indonesia during the New Order government (19681998).

The objectives and learning outcomes of the "Sejarah Indonesia Kontemporer" course include, first, the learning outcomes of the study program, namely, students can show a responsible attitude towards work in their field of expertise independently as an attitudinal achievement. Students can analyze and develop the historical values of Indonesia as a knowledge achievement. Students can apply logical, critical, systematic, and innovative thinking in the context of developing or implementing science and technology that pays attention to and applies humanities values according to their field of expertise as the first general skill achievement. Students can demonstrate independent, quality, and measurable work as a second general skill achievement. Students can make a logical analysis of historical developments in Indonesia. Second, the achievements of the courses which include students being able to explain various forms of government systems that prevailed in Indonesia from the beginning of independence to the fall of the New Order regime in the late 1990s. In addition, students can present the dynamics of the existence of political parties and parliaments in Indonesia In the period 1945-1990s. Finally, students can explain the economic, military, and political upheaval phenomena that have occurred in Indonesia in the 1945-1990s eras.

This course is designed to make an important contribution to the competence and profile of graduates of the Department of History, Faculty of Humanities, Andalas University. Contribution of the course "Sejarah Indonesian Kontemporer" to the competence and profile of graduates is that students can become "Historical Researchers". 
The main problem of this writing departs from the fact that students are relatively passive in responding to the teaching materials given to them. This passivity is related to their difficulty in understanding course material that is far from their contemporary imagination as millennial students. Therefore, all explanations and expectations for SCL implementation have not been maximally realized. Students are not challenged to understand all the aspects determined in the learning outcomes of "Sejarah Indonesia Kontemporer" course. Their duties and activities were far from what were expected. This passivity has been the cause of a certain practice, namely the tendency to see "www.google.com" as the answer to all questions about recent historical issues. This problem eventually leads to "copy-paste" mentality. They are relatively unable to answer the challenges of historical scholarship amid advances in information technology, an increasingly critical society, and the Indonesian crisis.

For this reason, this study proposes several research problem formulations as follows; first, what kind of historical learning method is suitable to be applied to millennial students today who have experienced Indonesian disruption? Second, can the "Free Learning- Independent Campus" (Kampus MerdekaMerdeka Belajar) method introduced by the Ministry of Education and Culture today be a solution? Therefore, the purpose of this paper is to describe the application of the teaching method "Independent Learning- Independent Campus" in the "Contemporary Indonesian History" class in the mid-semester of the 2019/2020 school year through the students' "Independent Project".

\section{METHOD}

This research on student experiences in the process of developing the Kampus-Merdeka, Merdeka-Belajar method is qualitatively based on their independent project data [1]. The independent project in question is the making of a video that demonstrates their understanding of the materials that has been given to the class. The history videos made by the students include their understanding of the context of space and time, namely the history of Indonesia from 1945 to the present. The context of space and time in the historical period is not limited to one event but is broader under the definition of historical studies, as well as students' understanding of the material that has been given in class [2]. For this reason, the application of an independent project method through historical videos in this study includes ideas, technical-historical narratives, and student experiences in the field.

The data obtained in the form of historical videos were obtained from an independent project of Andalas University history students as participants. Participants in this study were limited to students taking the course of "Sejarah Indonesia Kontemporer" who were in the odd semester of the 2019/2020 school year. Forty-five students took this course.

In the data collection process, information technology media are used, namely the Youtube channel and Google form, as the basis for analysis, interpretation, and development of a post-research action [2] [3]. The Youtube channel used is called "Studio Lapanduo", while the google form is called "Kuisioner Kuliah Sejarah Indonesia Kontemporer ". The use of research instruments via Youtube and Google forms includes three data fields. First, data related to historical ideas revealed by students. Second, the technical-historical narrative of the students as seen from the viewers with their likes and dislikes and comments. Third, experience as material for methodical evaluation of learning.

\begin{tabular}{|l|l|l|l|}
\hline Coding & Strategic & Media & Exploration \\
\hline $\begin{array}{l}\text { Historical } \\
\text { Ideas }\end{array}$ & & & \\
\hline $\begin{array}{l}\text { Technical- } \\
\text { historical } \\
\text { narrative }\end{array}$ & & & \\
\hline Experience & & & \\
\hline
\end{tabular}

The research took place from February-April 2020. Students were divided into thirteen groups. As long as students make independent projects, they are absent from class eight times. Their presence in class is replaced by the videos they produce. At the final meeting before the final semester exams, the research team distributed questionnaires to students to get responses to the learning methods applied to them in the middle of last semester, whether they were effective, efficient, fun, and independent of learning according to students.

Historical video data and evaluation via Google form provided by students are classified thematically to reinforce the use of the independent project giving method as a course development of "Sejarah Indonesia Kontemporer". Data grouping also considers aspects that include ideas, technical-historical narratives, and experiences gained by students. Data were analyzed through stages; data description, and interpretation. Description of data is done to show the process of student creativity and technical ideas. The interpretation is carried out by paying attention to the sociological context of the millennial generation who are the consumers of the produced historical videos. The analysis stages above are the basis for making conclusions. 


\section{RESULT AND DISCUSSION}

Based on the data collected through the YouTube channel playlist called "Studio Lapanduo", ninety-nine videos were collected within the period of three months. The videos are a collection from thirteen student groups. The average group produced seven videos. The group videos changed a lot from the plans they presented at the beginning of the class. The average duration is five to ten minutes.

Historical ideas conveyed in the video content of the students are not far from their daily lives. There are six historical ideas from the videos, namely; regarding the biographies of historical figures such as Sutarmi, Pangeran Diponegoro, Patimura, Hamka, Kartini, Sukarno, Gusti Nurul; rereading and interpreting patriotic songs of national struggle; historical monuments, health history, book reviews, and social history.

Technically, their video narrative was initially very stiff and monotonous. However, with various notes and input from the team as well as comments from viewers, there are relatively good changes in the next versions. A significant impact when it was still very simple was the average number of views and likes from video viewers, which only numbered tens. Few videos reached hundreds of viewers. Also, mediocre quality makes viewers rarely comment on the video production. Figure 1 shows the number of likes and comments on "Studio Lapanduo" videos.

Figure 1 Number of views and comments per video

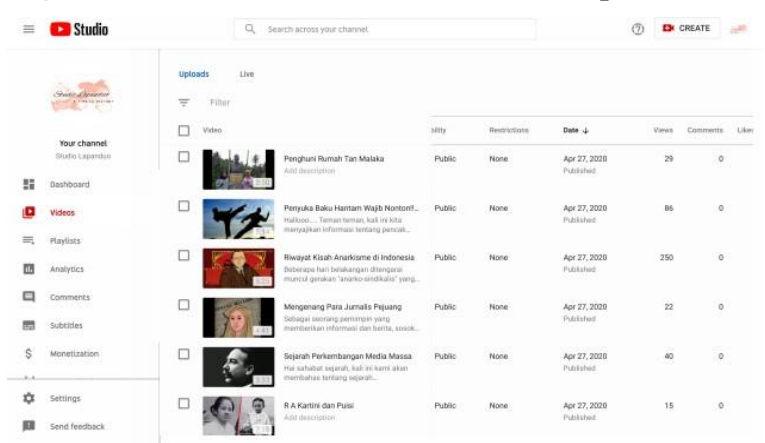

The team gave students the freedom to use the media used in producing their videos. Most of them use their cellphones. They only use the default application for editing videos. Others use a free "Kine Master" application. Nevertheless, students of contemporary Indonesian History course tried to play on the exploration of historical ideas, rather than paying attention to the technical side of a picture or the feasibility of a cinematic video. This exploration was shown in the evaluation results through questionnaires to them at the end of the course.

The final responses to the questionnaire were distributed through the WhatsApp group for the course, from forty-five students who took the course, two people did not follow the lecture at the beginning, and thirty-five others filled out the course evaluation questionnaire. The composition of the evaluation questionnaire respondents is shown in Figure 2 below.

Figure 2 Number of Respondents

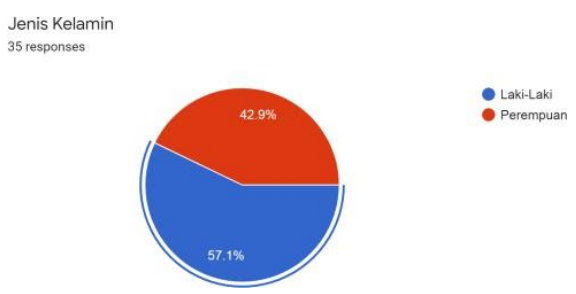

The results of the methodical evaluation of learning show that more than half of the students of the Sejarah Indonesia Kontemporer course prefer projects outside the classroom, the other is discussion. Meanwhile, lecturers gave the material a low percentage. Figure 3 below can provide an overview of students' desires for learning methods.

Figure 3 Learning methods that students prefer
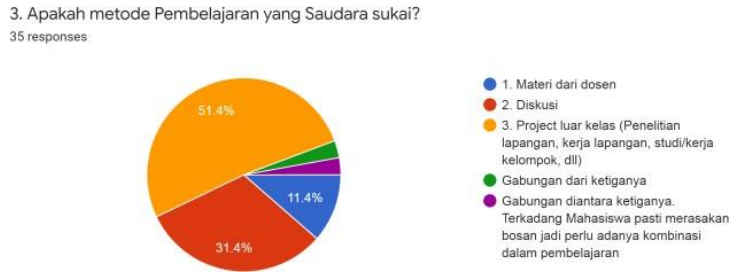

From the data above, it can be seen that the two most preferred learning methods for history students who take Sejarah Indonesia Kontemporer course are outside-class projects and discussions at $82.8 \%$. The reasons they chose projects outside the Classroom were: helping them improve the ability to think critically about problems that exist in society $(38.1 \%)$, providing a better empirical experience $(34.8 \%)$, providing the ability to work in groups (13\%), and providing the ability to communicate with the community $(8,7 \%)$. The remainder is a combination of the above options.

While students who saw discussion as a learning method conveyed that discussion gave them the ability to argue and present their ideas (39.1\%), allowed them to get feedback on ideas from other parties $(34.8 \%)$, received new ideas from discussion partners (13\%), gained new experiences $(8.7 \%)$, and other combined options above.

Meanwhile, on the exploration side, the experiences of the independent projects given to them were as follows. Students who consider it very good and satisfied with the learning method based on an independent project are $65.7 \%$, and those who consider it sufficient are $25.7 \%$. Figures 4 and 5 below can provide a clearer picture of students' answers related to the implementation of independent learning methods through independent projects. 
Figure. 4

6. Bila Saudara menjawab pertanyaan nomor 3 di atas; "PROJECT LUAR KELAS (PENELITIAN LAPANGAN, KERJA LAPANGAN, STUDI/KERJA KELOMPOK, DLL)", alasannya adalah: 23 responses
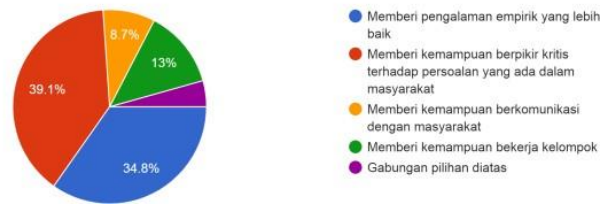

Figure 5

5. Bila Saudara menjawab pertanyaan nomor 3 di atas; "DISKUSI", alasannya adalah: 23 responses
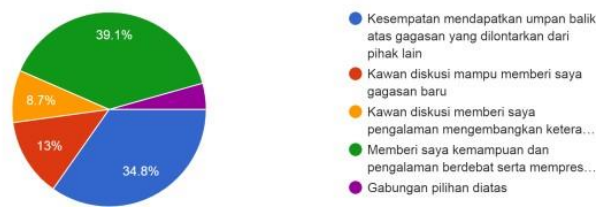

Qualitatively, students are also asked to provide a statement regarding the learning method through this independent project. Below are some of the statements they provide about the experience of creating historical video content.

"The memorable experience is that with this kind of learning method I can uncover facts in the field and visit unique places that have historical value."

"In the outdoor lecture method, there are often debates, especially in determining the topic of discussion and the ability to cultivate and explore the topic. So often some minor conflicts arose between group members. At least in this outdoor method, we can gain experience of working together and solidarity in groups. "

"My interesting experience is in the task of making videos, I learned many things, especially how to blend in with the public at large."

"With the task/project of Sejarah Indonesia Kontemporer in a group/team in the form of making a short video about the history of a place/biography of a character, I can deepen and expand knowledge that I did not previously know."

"As long as I study Sejarah Indonesia Kontemporer, I have gained experience and the development of ideas that I have not yet issued. In group learning, collaboration is needed so that it can form a good work team and get satisfactory value results. I am quite satisfied with studying Sejarah Indonesia Kontemporer. Thank you."

\section{CONCLUSION}

The method of "Merdeka Belajar-Kampus Merdeka" through the "Independent Project" is relatively successful, effective, efficient, and able to generate interest and make students more enthusiastic about understanding history. For this reason, the RPS of
Sejarah Indonesia Kontemporer will be revised. The revision will pay attention to methodological elements, learning outcomes, and appropriate assessments, to facilitate students in generating new ideas on Indonesian history. Also, through the method implemented, it appears that students are more innovative and

independent. They seem to possess a creative culture and have gained valuable knowledge and experience in shaping their academic character.

Through the development method that has been carried out, students seem enthusiastic in generating ideas and are creative in understanding and describing what they know, which is beyond the expectations of the lecturers. This means that with this method, students themselves are challenged to explore their academic potentials with the use the media of technology and the latest information technology to help the development of historical scholarship. This is proven by the variety of historical video contents that they produced on the YouTube channel. For this reason, the team immediately revised the RPS for this course, by making adjustments to what had been done through this research.

\section{ACKNOWLEDGMENTS}

This work was supported by financial funding of LP3M Andalas University in 2020.

\section{REFERENCES}

[1] D. J. P. Tinggi, Buku Saku Panduan Merdeka Belajar Kampus Merdeka, Jakarta: Dikti, 2020.

[2] D. J. P. Tinggi, Buku Saku Panduan Merdeka Belajar Kampus Merdeka, Jakarta: Dikti, 2020.

[3] C. A. Mertler, Penelitian Tindakan Kelas, Jakarta: Indeks, 2014.

[4] D. Yudhistira, Menulis Penelitian Tindakan Kelas Yang Apik, Jakarta: Grasindo, 2013 